\title{
Geotechnical and Physico-Chemical Characterization of Low Lime Fly Ashes
}

\author{
Arif Ali Baig Moghal \\ Department of Civil Engineering, College of Engineering, King Saud University, P.O. Box 800, Riyadh 11421, Saudi Arabia \\ Correspondence should be addressed to Arif Ali Baig Moghal; reach2arif@gmail.com
}

Received 3 January 2013; Accepted 17 February 2013

Academic Editor: Jacques Huot

Copyright ( 2013 Arif Ali Baig Moghal. This is an open access article distributed under the Creative Commons Attribution License, which permits unrestricted use, distribution, and reproduction in any medium, provided the original work is properly cited.

\begin{abstract}
In order to explore the possibility of using low-lime fly ashes, the physical and chemical properties which have a direct bearing on their geotechnical and geoenvironmental behaviors have been investigated. In this paper, two types of low-lime fly ashes, originating from India, have been used. A brief account of various methods adopted in characterizing their physical, chemical, and geotechnical properties is presented. The relative importance of each of these properties in enhancing the bulk applicability of fly ashes has been brought out.
\end{abstract}

\section{Introduction}

Electricity is the lifeline to a civilization. Ever since burning of coal for power generation began globally in the early 1920s, many millions of tonnes of ash and the related byproducts are also being created at an alarming rate. In India, the current annual production of fly ash is 70 million tonnes and is likely to increase to 80 million tonnes by the end of 2013. Disposal of huge quantities of fly ashes without proper care causes considerable impact on the environment, particularly the one leading to soil and groundwater contamination. Accordingly, the Ministry of Environment and Forests, Government of India [1], has established the basic framework for the advancement of fly ash utilization and environment conservation efforts in the country. According to it, the existing thermal power plants have to achieve $20 \%$ utilization of fly ash within 3 years and $100 \%$ utilization within 15 years, whereas the newly commissioned thermal power plants are required to achieve $30 \%$ utilization of fly ash within 3 years followed by $100 \%$ utilization within 9 years from their commencement.

On the other hand, fly ashes have many desirable properties which can be utilized in geotechnical and geoenvironmental engineering applications. While class $\mathrm{C}$ fly ashes with both self-cementing and pozzolanic properties are well utilized, class F fly ashes having higher pozzolanic ability remain underutilized and they form a considerable portion of fly ashes that are disposed. In this study, two types of low-lime fly ashes are characterized based on physical, chemical, and engineering properties for their suitability in various geotechnical and geoenvironmental applications. A brief overview of experimental methodology adopted for characterizing the fly ashes has also been presented.

\section{Fly Ashes Used}

Two low-lime fly ashes collected directly from the electrostatic precipitators of the thermal power plants located at Neyveli town $\left(11^{\circ} 36^{\prime} 28.39^{\prime \prime} \mathrm{N}\right.$ and $\left.79^{\circ} 29^{\prime} 28.81^{\prime \prime} \mathrm{E}\right)$ of Tamil Nadu and Muddanur town $\left(14^{\circ} 41^{\prime} 01.43^{\prime \prime} \mathrm{N}\right.$ and $\left.78^{\circ} 23^{\prime} 32.71^{\prime \prime} \mathrm{E}\right)$ of Andhra Pradesh, India, named NFA and MFA, respectively, have been characterized in the present study. Location map of these two thermal power plants is given in Figure 1.

\section{Chemical Composition}

Chemical composition of fly ashes which depends mainly on the origin of the coal was determined by conventional methods after fusion with carbonate. Table 1 shows the chemical composition of both fly ashes expressed in percentages with respect to the weight of fly ash. Like other fly ashes, these fly ashes also contain large amounts of silica and alumina. NFA 


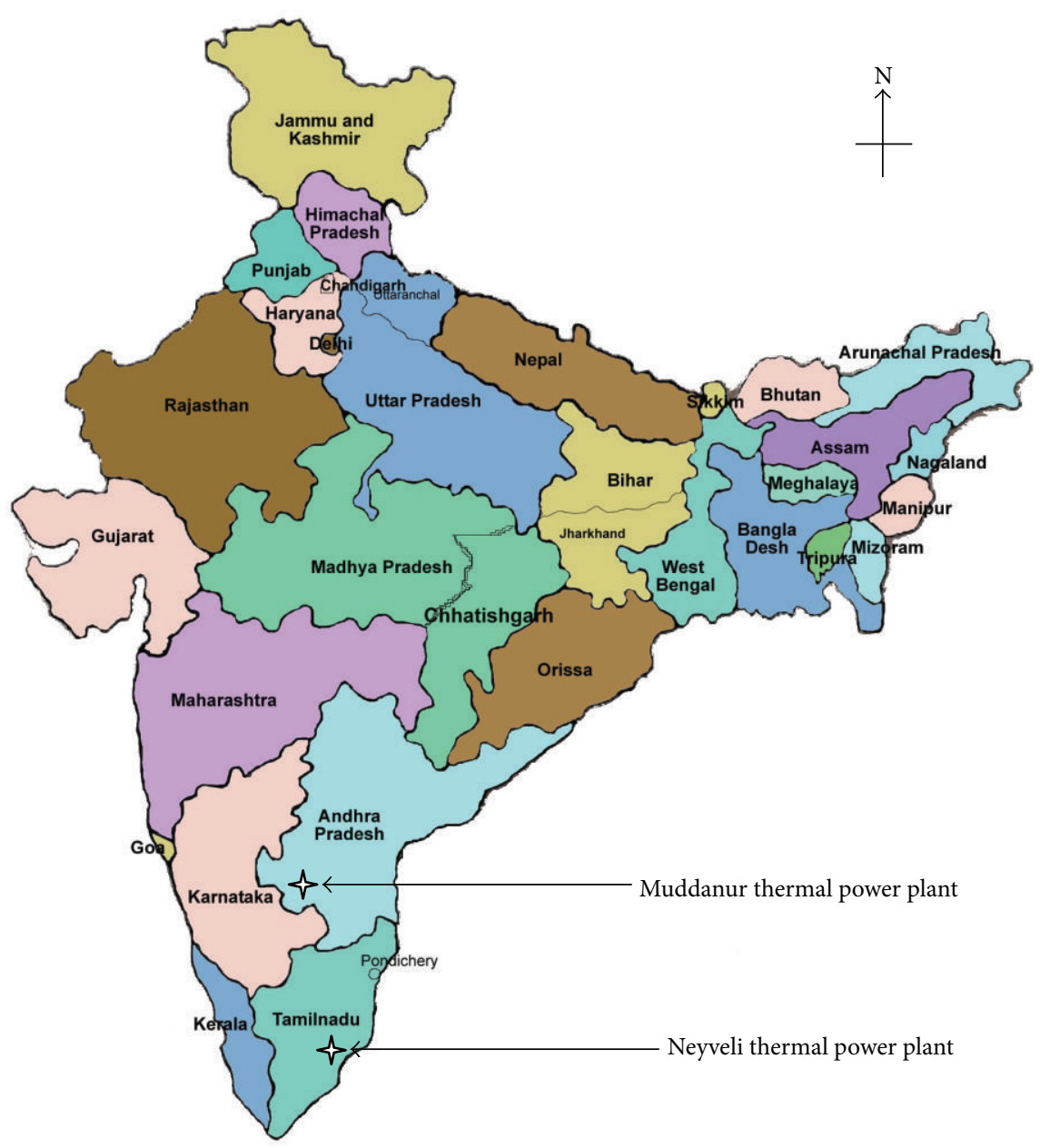

FIGURE 1: Location map of the thermal power plants (map not to scale).

has greater ferric oxide content than MFA. The difference in specific gravity values of fly ashes is due to the difference in ferric oxide contents present in them. Both fly ashes can be classified as class "F" type as per ASTM C618 [2] classification based on total calcium content.

\section{Physical Properties}

4.1. Specific Gravity. Specific gravity of fly ash depends considerably upon its iron content, which increases the specific gravity and carbon content, which decreases the specific gravity. Specific gravity of the fly ashes used was determined as per ASTM D854-06 [3] using pycnometer and kerosene and an average value of three tests has been reported. Individual determinations differed from the mean by less than or equal to 0.01 . Specific gravity values of NFA and MFA were observed to be 2.83 and 2.17 , respectively. The relatively lower unit weight's are of advantage in the case of its use as a backfill material for retaining walls since the pressure exerted on the retaining structure as well as the foundation will be less. The other areas of application include embankments especially on weak foundation soils
TABLE 1: Chemical composition of fly ashes.

\begin{tabular}{lcc}
\hline Constituent & NFA (\%) & MFA (\%) \\
\hline Silica $\left(\mathrm{SiO}_{2}\right)$ & 50.97 & 56.88 \\
Alumina $\left(\mathrm{Al}_{2} \mathrm{O}_{3}\right)$ & 18.81 & 27.65 \\
Ferric $\left(\mathrm{Fe}_{2} \mathrm{O}_{3}\right)$ & 16.61 & 6.28 \\
Calcium $(\mathrm{CaO})$ & 9.00 & 3.62 \\
Magnesium $(\mathrm{MgO})$ & 1.41 & 0.34 \\
Titanium $\left(\mathrm{TiO}_{2}\right)$ & 0.28 & 0.31 \\
Potassium $\left(\mathrm{K}_{2} \mathrm{O}\right)$ & 0.23 & 0.27 \\
Sodium $\left(\mathrm{Na}_{2} \mathrm{O}\right)$ & 0.18 & 0.19 \\
Loss on ignition & 2.60 & 4.46 \\
\hline
\end{tabular}

and reclamation of low-lying areas. The reason for a low specific gravity is due to the presence of a large number of hollow cenospheres from which the entrapped air cannot be removed, or the variation in the chemical composition, in particular the iron content, or both [4].

4.2. Specific Surface Area. The surface area of particles is important because it controls the total adsorption capacity 
to some extent. The surface areas of fly ash particles generally vary inversely with the particle size (i.e., the smaller the particle, the larger the surface area). Schure et al. [5] performed a series of tests determining the surface area and porosity of Western coal fly ash. They found, for the 0-74 $\mu \mathrm{m}$ particle size range, the surface area did in fact decrease with increasing particle size. However, for particles over $74 \mu \mathrm{m}$ the shape deviates from the spherical one and takes irregular sponge-like shape which in turn increases the surface area. The larger particle sizes are usually carbonaceous which indicates that they are likely the result of incomplete combustion. El-Mogazi et al. [6] found the surface areas range to be from 0.45 to $1.25 \mathrm{~m}^{2} / \mathrm{g}$. Mattigod et al. [7] indicate a slightly wider range from 0.2 to $3.06 \mathrm{~m}^{2} / \mathrm{g}$. Theis and Gardner [8] report unusually high surface areas of $1-9.44 \mathrm{~m}^{2} / \mathrm{g}$. However, they also reported a wide range of particle sizes $(0.01-125 \mu \mathrm{m})$, indicating probably that the samples were taken from different stages of combustion. The specific surface area was determined by water adsorption study. Adsorption of water vapor at $23^{\circ} \mathrm{C}$ was obtained using plastic desiccator, containing $2 \mathrm{~g}$ of fly ash sample dried earlier for $24 \mathrm{~h}$ at $110^{\circ} \mathrm{C}$. For controlling the water activity at 0 , 52 , and 100 percent relative humidity (RH), dry phosphorus pentoxide, oversaturated solution of sodium dichromate, and distilled water were used, respectively. These were used to keep water activity of air constant in the plastic desiccator and surrounding sample contained in the glass jar. All such desiccators were kept at a constant room temperature of $23^{\circ} \mathrm{C}$. Weighing was done every 2 days by a digital balance (accuracy $=0.0001 \mathrm{~g}$ ) until apparent equilibrium was reached. The procedure of determining specific surface area involves the determination of the number of molecules of gas required to form a monolayer on the surface of the material. Though nitrogen gas is more commonly used, water adsorption is preferred for plastic and nonplastic materials as both external and internal areas are covered by water unlike nitrogen where only external surface is covered [9]. Data from water adsorption at 52\% RH can be used to calculate the specific surface of the plastic and nonplastic materials [10]. It can be assumed that a monolayer of water is adsorbed on these materials at this humidity. If the cross-sectional area of the adsorbate (e.g., water) molecule is known, the total surface area $\left(S_{t}\right)$ and specific surface area $(S)$ of the adsorbent may be approximated from the mass of adsorbate at monolayer coverage as follows [11]:

$$
S_{t}=\frac{\left(X_{\mathrm{tm}} N A\right)}{M} \times 10^{-20} \mathrm{~m}^{2},
$$

where $X_{\mathrm{tm}}$ (gram) is the total monolayer weight of the adsorbate, $M$ the molecular mass of the adsorbate, $N$ the Avogadros number $\left(6.02 \times 10^{23}\right.$ molecules/mole), and $A$ the adsorbate cross-sectional area in $\AA^{2} /$ molecule. The crosssectional area for adsorbate $\mathrm{H}_{2} \mathrm{O}$ at $25^{\circ} \mathrm{C}$ can be approximated as $10.8 \AA^{2}$ [11]. Total surface area $\left(S_{t}\right)$ is divided by the adsorbent mass to obtain the specific surface area $(S)$. The mass of water adsorbed at $52 \% \mathrm{RH}$ is taken as $X_{\mathrm{tm}}$, that is, the total monolayer weight of the adsorbate. On the basis of previous equation, specific surface area of fly ash was

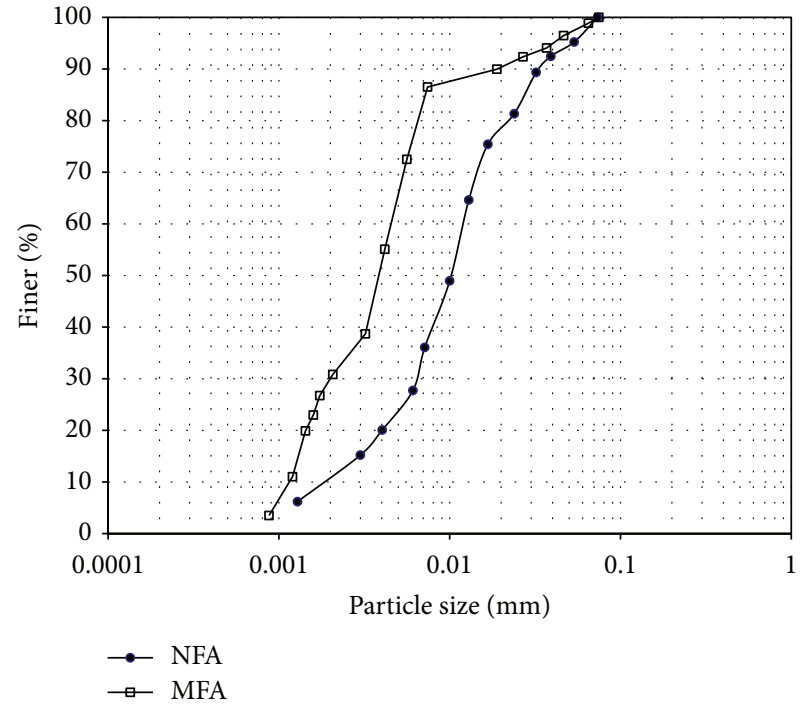

FIgURE 2: Particle size distribution curves of NFA and MFA.

calculated. The specific surface areas of NFA and MFA were found to be 9.6 and $8.2 \mathrm{~m}^{2} / \mathrm{gm}$, respectively.

4.3. Particle Size Distribution. Fly ash is the portion of combustion solid waste residue with small enough particle size to be carried away in the flue gas. 80 to $99 \%$ of fly ash sample by weight passes $74 \mu \mathrm{m}$ screen size. Fly ash is generally fine grained and falls within the silt range $(2 \mu \mathrm{m}$ to $74 \mu \mathrm{m})$ [12]. Fly ashes disposed off by wet ash disposal system and deposited near the discharge area show more than $50 \%$ fine sand range of particles. Fly ashes, which are deposited away from the discharge unit, show more than $50 \%$ silt range particles. The extensive investigations carried out on Indian coal ashes $[13,14]$ demonstrate that the fly ashes consist predominantly of silt-size fraction with some claysize fraction. In pond ashes, silt-size fraction predominates with some sand-size fraction. The bottom ashes are coarser particles consisting predominantly of sand-size fraction with some silt-size fraction. Based on the grain-size distribution, the coal ashes can be classified as sandy silt to silty sand. In the present study, particle size distribution curves of the fly ashes passing through $75 \mu \mathrm{m}$ were arrived at as per ASTM D42263 [15]. Figure 2 shows the particle size distribution curves of these fly ashes. It is observed that MFA has greater finer particle content than NFA. Particle size analysis based on laser diffraction as per ASTM B822-02 [16] was also carried out. This principle relies on the fact that particles passing through a laser beam will scatter light at an angle that is directly related to their size. As particle size decreases, the observed scattering angle increases logarithmically. Scattering intensity is also dependent on particle size, diminishing with particle volume. Larger particles, therefore, scatter light at narrow angles with high intensity whereas smaller particles scatter light at wider angles but with low intensity. Figures 3(a) and 3(b) show particle size distribution curves for NFA and MFA using laser diffraction analysis. It is again observed that MFA has greater finer particle content than that of NFA. 


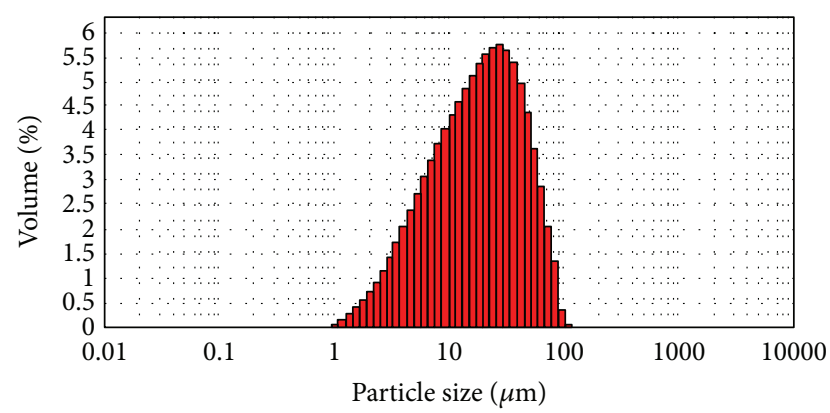

(a)

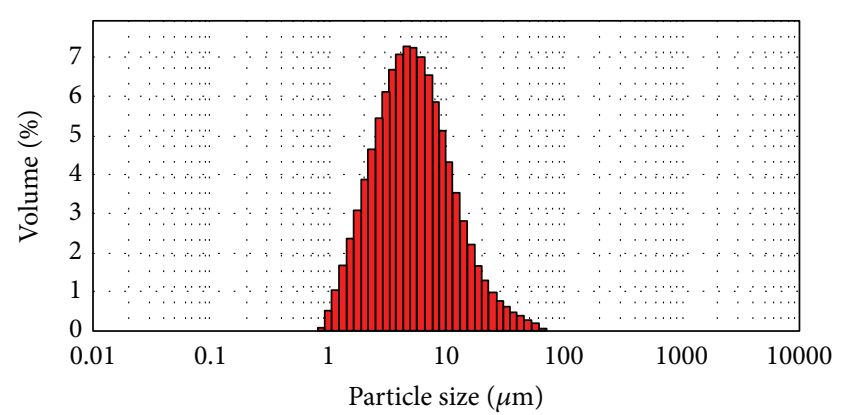

(b)

FIgURE 3: (a) Particle size distribution curve for NFA using laser diffraction analysis. (b) Particle size distribution curve for MFA using laser diffraction analysis.

4.4. X-ray Diffractograms. The presence of different phases in fly ashes necessitates thorough $\mathrm{X}$-ray diagnosis. It is known that different phases of fly ashes yield different diffraction patterns. This makes X-ray diffraction a powerful tool for the study. In the present investigation, XRD was carried out using Bruker D8 Advance system. Samples were scanned from $5^{\circ}$ to $80^{\circ}(2 \theta)$ using a $2.2 \mathrm{~kW} \mathrm{Cu}$ anode long, fine focus ceramic X-ray tube at a scanning rate of 1 degree per minute. XRD patterns of samples were then compared with the standard patterns of possible types of compounds to identify the new compounds (JCPDS). Figure 4 shows the Xray diffractograms of NFA and MFA. It is observed that quartz and mullite phases are predominant in both fly ashes.

4.5. Scanning Electron Micrograph. The Sirion high-resolution scanning electron microscope (SEM) equipped with a Schottky field emission source with high-voltage variables between $20 \mathrm{kV}$ and $30 \mathrm{kV}$ was employed for examining the surface characteristics of both fly ashes. A very small amount of oven-dried and finely powdered fly ash sample was mounted onto the tape glued to the flat surface of SEM stub and sputter coated with gold prior to scanning [17]. Figure 5 shows the SEM images of NFA and MFA. The surface morphology of MFA reveals that it possesses rough surface compared to that of NFA.

4.6. Atterberg's Limits. The properties such as liquid limit, plastic limit, and plasticity index are most commonly used in the geotechnical engineering field. These characteristics are not only important in classification and identification but also in predicting engineering behaviors such as strength, hydraulic conductivity, and compressibility. Liquid limit test in the present study was performed by the cone penetration method [18] because of its simplicity and reproducibility of test results. Liquid limit values of NFA and MFA were observed to be $39 \%$ and $29 \%$, respectively. Since the fly ashes are nonplastic in nature, plastic limit and plasticity index values do not arise for them.

4.7. Compaction Characteristics. The density of coal ashes is an important parameter since it controls the strength, compressibility, and permeability. In general, fly ashes show considerable variation in compaction due to the variation in the nature of fly ash produced from the same power plant over time $[19,20]$. The variation of dry density with moisture content for fly ashes is less compared to that for a wellgraded soil, both having the same medium grain size [21]. In the present study, the maximum proctor density values corresponding to each of the fly ashes were determined by employing the minicompaction test procedure developed by Sridharan and Sivapullaiah [22].

For each compaction test, about $200 \mathrm{~g}$ of fly ash was used. Required amount of water was added to the fly ash and mixed thoroughly and stored in a polythene bag for moisture equilibrium. After allowing sufficient time for moisture equilibrium, the sample was remixed thoroughly before compaction. The fly ash was compacted in the mold in three layers. The weight of the compacted fly ash together with the mould was found out and the weight of the compacted fly ash was determined. Water content of the representative sample from the middle layer was found out accordingly. The compaction was repeated until the fly ash became sticky and wet. The results of the compaction test were presented in a plot of dry density versus water content. From the plot, maximum dry density and optimum water content were determined. Proctor maximum dry density values of NFA and MFA were observed to be $14 \mathrm{kN} / \mathrm{m}^{3}$ and $13.3 \mathrm{kN} / \mathrm{m}^{3}$ and the optimum water content values were 24 and $23.8 \%$, respectively (Figure 6). These values are characteristic of typical silty loam soils, which exhibit better drainage and infiltration characteristics.

4.8. Unconfined Compression Strength. The strength behaviour of fly ashes assumes great importance in their use for various geotechnical applications. The strength of fly ash basically determines both the steepness of fill slopes as well as the magnitude of the foundation loads it can support. For retaining walls, the shear strength of the backfill determines the load the wall can support. Shear strength defined by cohesion and angle of internal friction is used in the design of fly ash embankments and backfills. The greatest advantage of pozzolanic materials such as fly ash is that the cohesion improves with the curing period increasing in turn the stability of structures. 


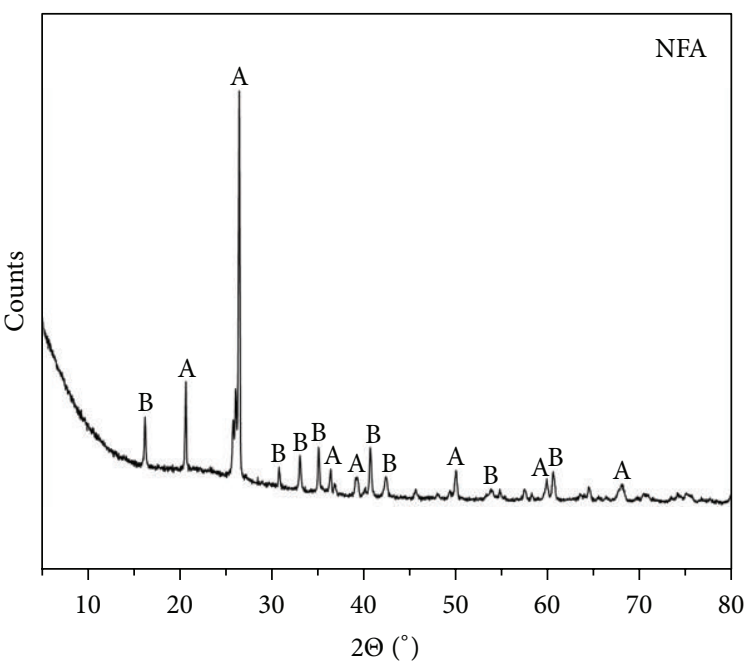

A: quartz B: mullite

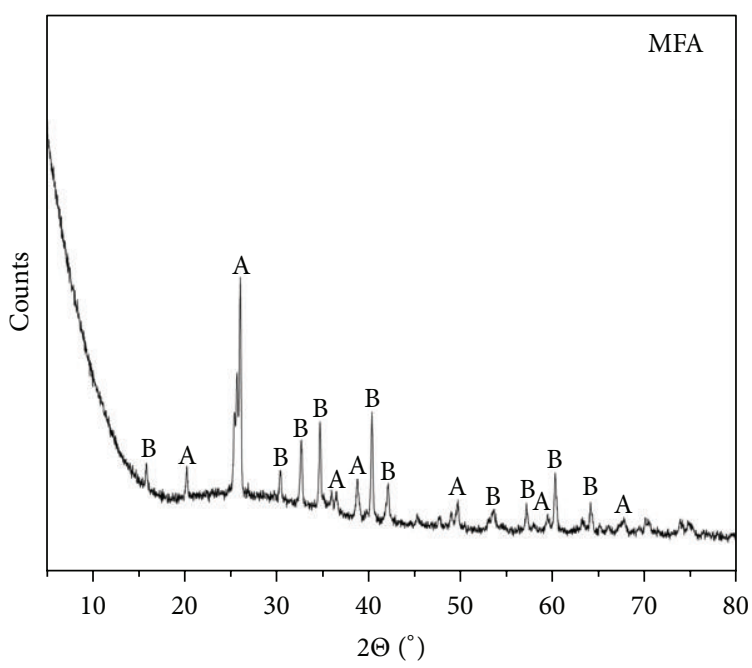

A: quartz B: mullite

(a)

(b)

Figure 4: X-ray diffractograms of NFA and MFA.
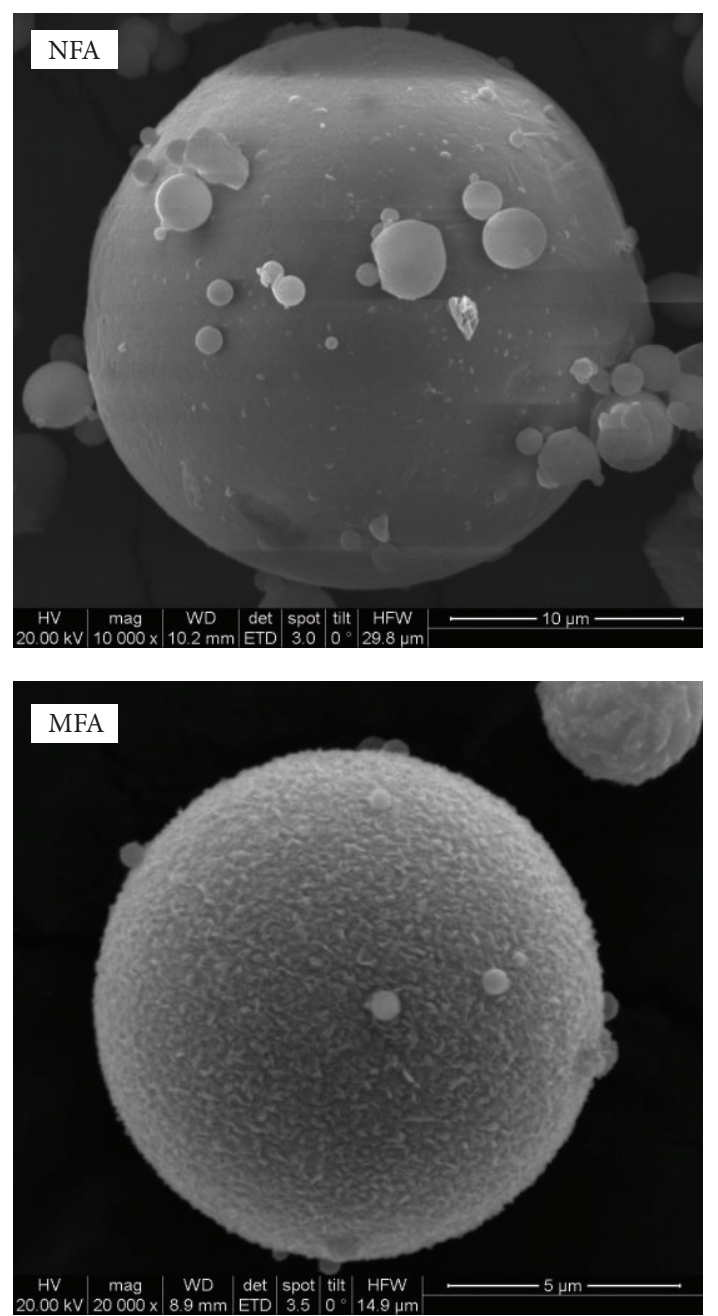

FIGURE 5: SEM images of NFA and MFA.

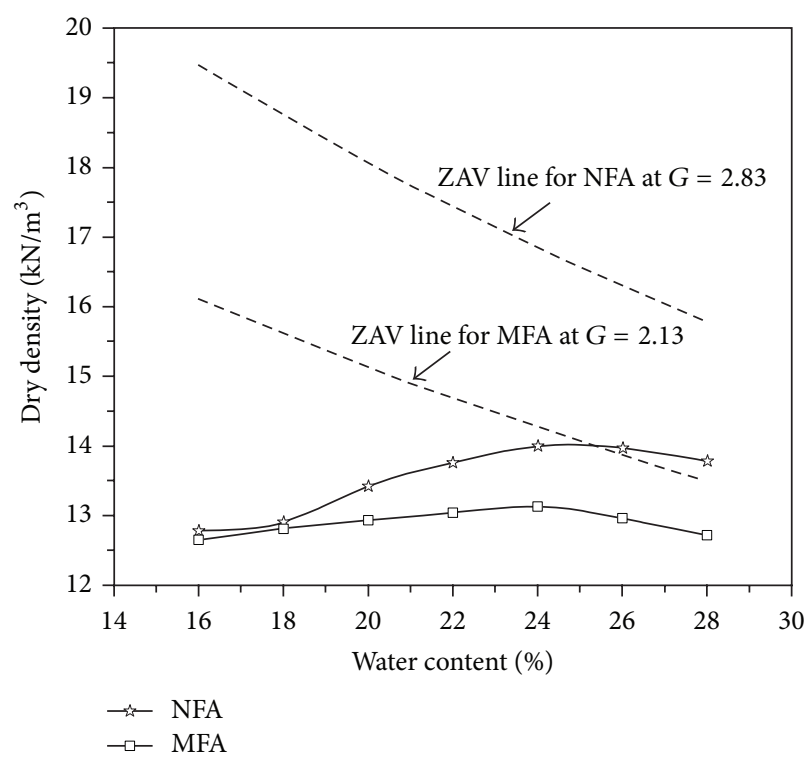

FIGURE 6: Dry density and water content relationships of the fly ashes.

The samples were prepared and tested as per ASTM D2166 [23] and sheared at a strain rate of $0.05 \mathrm{~mm} / \mathrm{min}$. From the stress strain curves, the magnitudes of the peak stress and strain values corresponding to peak stress were noted. In order to study the effect of curing on the unconfined compressive strength, the compacted specimens were kept in an airtight desiccator maintained at a relative humidity of more than $95 \%$ and cured up to 180 days as per ASTM D5102 [24]. After the given curing period, the weight of the sample to be tested was noted and it was compared with its original weight. The specimen whose loss in moisture content due to the heat of hydration, if found more than $5 \%$, was rejected. 
Generally, most of the fly ashes exhibit lower unconfined compressive strength both in dry and fully saturated conditions due to the absence of cohesion for dry fly ash and loss of apparent cohesion upon total saturation [25]. However, the difference in capillary tensions between coarser and fine ashes attributes unconfined compressive strength values for fine ashes [26]. Thus, it can be seen from Figure 7 that for both fly ashes with different initial free lime contents the unconfined compressive strength increases with curing period. Further, the rate at which the strength gain occurs for the curing period considered in the study is significantly high for MFA with finer particles than NFA with relatively coarser particles.

4.9. California Bearing Ratio. Utilization of fly ash in the construction of road and railway embankments is a step vigorously pursued globally to overcome the environmental and economic issues associated with importing quality construction materials from nearby terrains [4]. Efforts to avert the problem have stimulated interest in utilizing alternative materials such as fly ashes which are ecologically safe and economically viable. For the use in highway embankments, fly ash and bottom ash mixtures were found to compare favorably with conventional granular materials [27]. CBR values of fly ashes vary considerably depending on the type of fly ash, nature, curing period, and the condition under which the test is conducted. In this study, CBR tests were carried out on fly ashes after curing the compacted specimens for 1,7 , and 14 days. As the soaked CBR values are to be used for the design of pavements since it depicts the worst case according to ASTM D1883-07E2, a series of soaked tests were also conducted for all the mixes after curing the moulds for 1 , 7, and 14 days. The loads corresponding to different depths of penetration for NFA and MFA after curing for 1,7 , and 14 days are recorded and the loads required for $2.5 \mathrm{~mm}$ and $5 \mathrm{~mm}$ penetrations obtained and presented in Table 2. The higher loads required for deeper penetration for fly ashes are due to the material possessing higher stiffness at lower strain levels. Thus, higher CBR values are observed for $5 \mathrm{~mm}$ depth compared to $2.5 \mathrm{~mm}$ depth of penetration for pozzolanic fly ashes as could be seen from the results presented in Table 2.

4.10. Hydraulic Conductivity. Hydraulic conductivity is an important parameter in the design of liners to contain leachate migration, dykes to predict the loss of water, embankments as well as the stability of slopes and as a subbase material [4]. The hydraulic conductivity of well-compacted fly ash has been found to range from $10^{-4}$ to $10^{-6} \mathrm{~cm} / \mathrm{s}$, which is roughly equivalent to the normal range of permeability of silty sand to silty clay soils [28]. The hydraulic conductivity of fly ash is affected by its density or degree of compaction, its grain size distribution, pozzolanic activity, and its internal pore structure $[29,30]$.

The hydraulic conductivity of a fly ash is generally affected by its density or degree of compaction, grain size distribution, and internal pore structure. Since fly ash consists almost entirely of spherical shaped particles, they get densely packed during compaction, resulting in the reduction of hydraulic conductivity values. The hydraulic conductivity of fly ash is

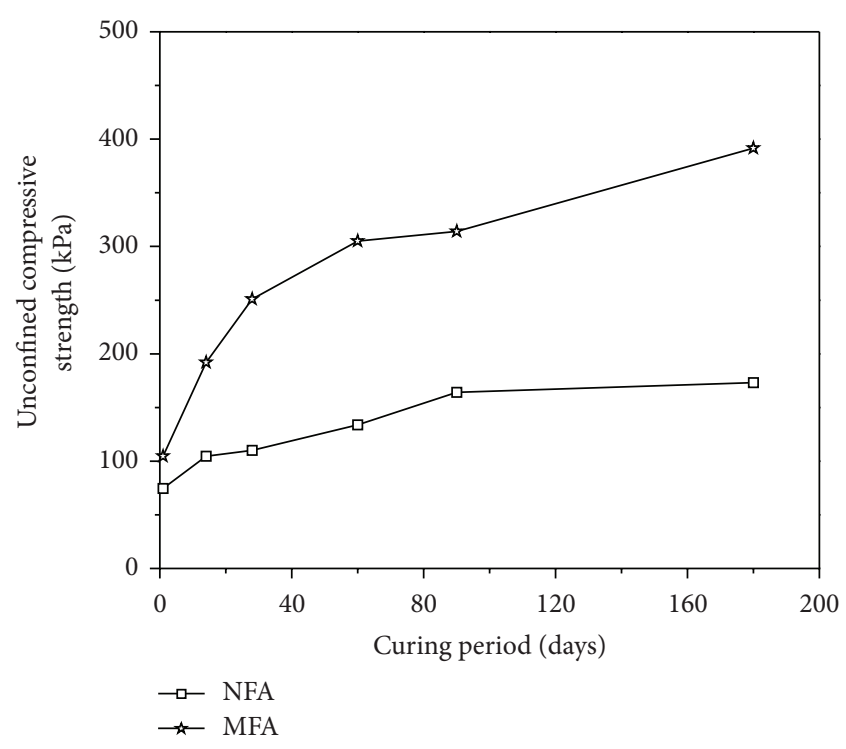

FIGURE 7: Variation of unconfined compression strength with curing period.

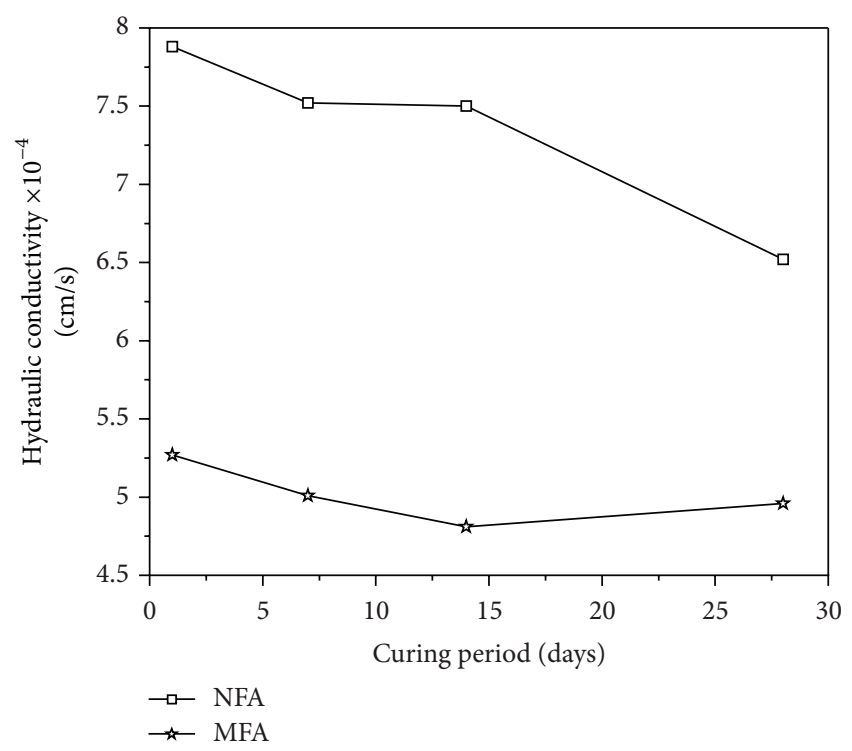

FIGURE 8: Variation of hydraulic conductivity with curing period.

high because of its particle size and nonplastic nature and is analogous to the characteristics of nonplastic materials such as silts. For hydraulic conductivity study, the samples were prepared and tested as per ASTM D2166 [23]. The hydraulic conductivity mold with the compacted specimen was kept in a desiccator maintained at a relative humidity greater than $95 \%$ and cured for 7,14 , and 28 days. At the end of each curing period, the hydraulic conductivity values were determined for both fly ashes. Figure 8 shows the variation in hydraulic conductivity values with curing period. With the increase in curing period, a marginal decrease in hydraulic conductivity values is observed which can be attributed to the formation of 
TABLE 2: Variation of CBR values for NFA and MFA under unsoaked and soaked conditions and at different curing periods.

\begin{tabular}{|c|c|c|c|c|c|c|c|c|c|c|c|c|}
\hline \multirow{3}{*}{ Mix } & \multicolumn{4}{|c|}{1 day } & \multicolumn{4}{|c|}{7 days } & \multicolumn{4}{|c|}{14 days } \\
\hline & \multicolumn{2}{|c|}{ Unsoaked } & \multicolumn{2}{|c|}{ Soaked } & \multicolumn{2}{|c|}{ Unsoaked } & \multicolumn{2}{|c|}{ Soaked } & \multicolumn{2}{|c|}{ Unsoaked } & \multicolumn{2}{|c|}{ Soaked } \\
\hline & $2.5 \mathrm{~mm}$ & $5 \mathrm{~mm}$ & $2.5 \mathrm{~mm}$ & $5 \mathrm{~mm}$ & $2.5 \mathrm{~mm}$ & $5 \mathrm{~mm}$ & $2.5 \mathrm{~mm}$ & $5 \mathrm{~mm}$ & $2.5 \mathrm{~mm}$ & $5 \mathrm{~mm}$ & $2.5 \mathrm{~mm}$ & $5 \mathrm{~mm}$ \\
\hline NFA & 28.9 & 36.0 & 1.3 & 1.1 & 50.4 & 47.2 & 40.7 & 39.9 & 54.1 & 55.5 & 51.1 & 53.0 \\
\hline MFA & 15.1 & 16.7 & 0.7 & 1.1 & 32.6 & 35.0 & 27.4 & 33.1 & 43.7 & 41.8 & 40.7 & 39.4 \\
\hline
\end{tabular}

pozzolanic compounds blocking the pores and reducing the fluid conduction.

4.11. Compressibility Characteristics. Compressibility characteristics of fly ash depend on its initial density, degree of saturation, self-hardening characteristics, and pozzolanic activity. Consolidation occurs more rapidly in compacted fly ash than in silty clay soil because partially saturated fly ashes are less compressible compared to fully saturated ones $[19,31,32]$. The compressibility of fly ashes reduces considerably with agehardening properties which in return reduce the time rate of consolidation as well as the magnitude of compressibility. In this study, compressibility characteristics of fly ashes are determined in accordance with ASTM D2435 [33]. The fly ashes after mixing with the amounts of water corresponding to their respective proctor maximum dry densities were compacted using static compaction technique in a cylindrical consolidation metal ring of $60 \mathrm{~mm}$ diameter and $20 \mathrm{~mm}$ height. The entire assembly was next mounted in the consolidation cell and positioned in the loading frame. A minimum duration of 24 hours was kept at each load increment. Both the samples were loaded to $800 \mathrm{kPa}$ starting from $6.25 \mathrm{kPa}$ and then unloaded, at a standard load increment ratio of unity for any specified duration of load increment. Figure 9 shows the void ratio-pressure relationships for fly ashes. It is observed that at any pressure the final equilibrium void ratio increases with the surcharge. Further, unlike clays which take long time to complete primary consolidation under any pressure increment, settlements occur immediately in case of fly ashes. Moreover, the rebound is marginally small as seen from Figure 9, which is similar to that exhibited by silty sands.

4.12. Free Swell Index. Free swell index is one of the most commonly used simple tests for getting an estimate of swell potential of any material. This test was first proposed by Holtz and Gibbs [34] and is expressed in cc or $\mathrm{mL}$ per one gram of material. The procedure established by Rao and Sridharan [35] has been followed in the present study for determining the free swell index. Oven-dried powdered sample of fly ash of $10 \mathrm{~g}$ was submerged in $40 \mathrm{~mL}$ of distilled water in a $100 \mathrm{~mL}$ standardized graduated cylinder. The suspension was repeatedly stirred for thorough mixing and was allowed to equilibrate for $24 \mathrm{~h}$ to ensure thorough wetting of the sample. The suspension was then made up to the $100 \mathrm{~mL}$ mark by proper stirring. The cylinder was covered with a cap and left undisturbed for a further period of $24 \mathrm{~h}$ at which time the volume occupied by the sample particles on settling was noted. After the suspension reached an equilibrium value,

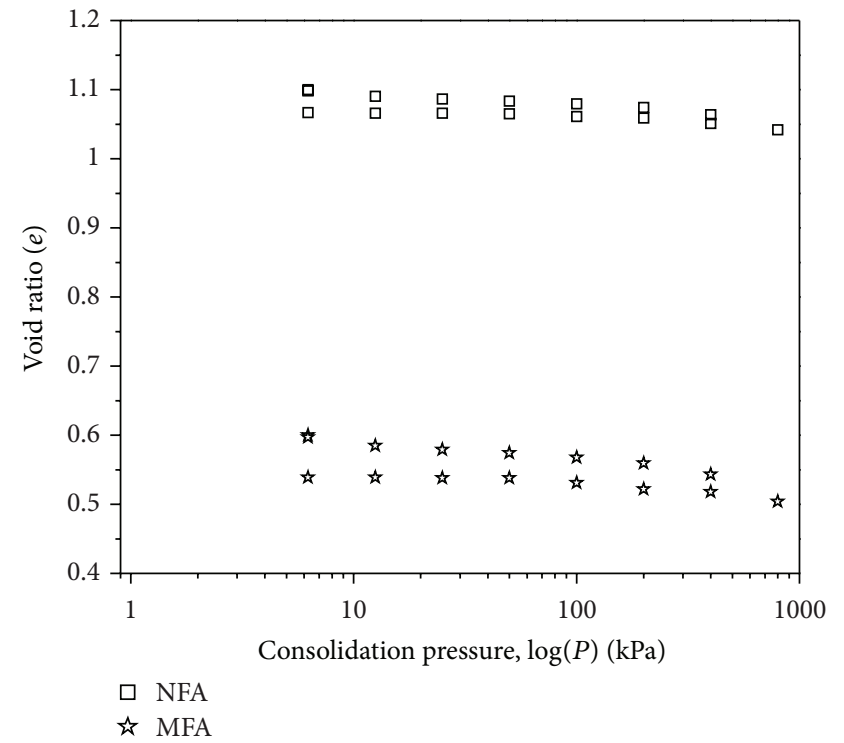

FIGURE 9: Compressibility behavior of NFA and MFA.

sediment volume was noted. The free swell index was then calculated as sediment volume per gram of fly ash; that is,

$$
\text { free swell index }=\frac{V_{d}}{W} \text { in cc/gm, }
$$

where $V_{d}$ is the equilibrium volume of the oven-dried fly ash sample read from the graduated cylinder and $W$ the weight of the oven-dried fly ash sample. The free swell index values obtained are 1.1 and $1.2 \mathrm{~cm}^{3} / \mathrm{g}$ for NFA and MFA, respectively. Based on these values, both fly ashes can be classified as nonswelling type [36].

4.13. Zeta Potential. Zeta potential is the electric potential in the interfacial double layer (DL) at the location of the slipping plane versus a point in the bulk fluid away from the interface. In other words, zeta potential is the potential difference between the dispersion medium and the stationary layer of fluid attached to the dispersed particle. A value of $25 \mathrm{mV}$ (positive or negative) can be taken as the arbitrary value that separates low-charge surfaces from high-charge surfaces. The significance of zeta potential is that its value can be related to the stability of colloidal dispersions. The zeta potential indicates the degree of repulsion between adjacent, similarly charged particles in dispersion. For molecules and particles that are small enough, a high zeta potential will confer stability; that is, the solution or dispersion will resist aggregation. When the potential is low, attraction exceeds 
repulsion and the dispersion will break and flocculate. So, colloids with high zeta potential (negative or positive) are electrically stabilized while colloids with low zeta potentials tend to coagulate or flocculate as outlined in Table 3. Zeta potential is widely used for quantification of the magnitude of the electrical charge at the double layer. The zeta potential values of NFA and MFA determined using Zetasizer Nano ZS, were found to be -38.3 and $-44.8 \mathrm{mV}$. Hence, colloids of both NFA and MFA show moderate-to-good stability to coagulate.

\section{Leachability of Trace Metal Ions}

Coal contains significant quantities of various trace elements and, during combustion of coal, trace elements are enriched as a result of carbon loss as carbon dioxide and the trace elements are associated with the surface of the ash particle due to evaporation and condensation. The characteristics of the coal used and the type of the installation employed in generating the solid combustion wastes (fly ash) have a direct influence on chemical and mineralogical composition of fly ash. The concentration associated with the ash may be either adsorbed on the surface of particle or incorporated into matrix [37]. Leaching tests are conducted to estimate the environmental impact under the assumed leaching conditions. They are also used as regulatory protocols and are designed for use over a wide range of applications and for a diverse set of purposes.

The laboratory leaching test for combustion residues developed by Van der Sloot et al. [38] has been adopted to investigate the leaching phenomenon from both fly ashes. The concentrations of trace elements present in both fly ashes have been determined using US EPA Method 3050B [39] and are presented in Table 4. For the digestion of samples, a representative 1-2 gram (wet weight) or 1 gram (dry weight) sample is digested with repeated additions of nitric acid $\left(\mathrm{HNO}_{3}\right)$ and hydrogen peroxide $\left(\mathrm{H}_{2} \mathrm{O}_{2}\right)$. For ICP-AES (inductively coupled plasma-atomic emission spectrometry) analysis, hydrochloric acid $(\mathrm{HCl})$ is added to the initial digestate and the sample is refluxed. In an optional step to increase the solubility of some metals, this digestate is filtered and the filter paper and residues are rinsed, first with hot $\mathrm{HCl}$ and then with hot reagent water. Filter paper and residue are returned to the digestion flask, refluxed with additional $\mathrm{HCl}$ and then filtered again. The digestate is then diluted to a final volume of $100 \mathrm{~mL}$. The elemental analysis is then performed using ICP-AES.

According to the laboratory leaching test for combustion residues developed by Van der Sloot et al. [38], the same quantity of fly ash residue is extracted for a number of times with fresh leaching agent. The test requires a liquid to solid ratio $(\mathrm{L} / \mathrm{S})$ from 5 to 100 . It was found that the period required to complete leaching was generally around 18 hours. With a buffer period of another 6 hours, the extraction time was taken as 24 hours. The extract was filtered through Whatman no. 42 filter paper to separate fly ash from the fluid. To save the trouble of rinsing, the ash was transferred along with the filter paper to the same bottle. For the next extraction, another aliquot of the same volume of fluid was added, which gives the cumulative liquid solid ratio twice that of the initial
TABLE 3: Stability behaviour of colloids at different zeta potential values.

\begin{tabular}{lc}
\hline Zeta potential $(\mathrm{mV})$ & Stability behaviour of the colloid \\
\hline 0 to \pm 5 & Rapid coagulation or flocculation \\
\pm 10 to \pm 30 & Incipient stability \\
\pm 30 to \pm 40 & Moderate stability \\
\pm 40 to \pm 60 & Good stability \\
$> \pm 60$ & Excellent stability \\
\hline
\end{tabular}

TABLE 4: Concentrations of trace elements in fly ashes ( $\mathrm{mg} / \mathrm{kg})$.

\begin{tabular}{lcc}
\hline Trace element & NFA & MFA \\
\hline $\mathrm{Pb}$ & 121.5 & 96.2 \\
$\mathrm{Zn}$ & 34.8 & 40.4 \\
$\mathrm{Mn}$ & 67.6 & 49.8 \\
$\mathrm{Cd}$ & 36.5 & 25.8 \\
$\mathrm{Cu}$ & 32.1 & 46.5 \\
$\mathrm{Cr}$ & - & 79.8 \\
\hline
\end{tabular}

ratio. This process was repeated till the liquid solid ratio of 100 was achieved. Another series of leaching tests were conducted where the $\mathrm{pH}$ of the fluid was varied from 2 to 10 . The $\mathrm{pH}$ of the solution was kept constant by suitably adding $\mathrm{HCl}$ and $\mathrm{NaOH}$ solutions and was monitored constantly using Jenway $\mathrm{pH}$ electrode. The fly ash was oven dried at $105^{\circ} \mathrm{C}$ for 2 hours prior to the conduction of the test. The $500 \mathrm{~mL}$ capacity polyethylene bottles which were used to carry out the leachability tests were kept soaked in $0.1 \mathrm{~N} \mathrm{HCl}$ for a week and were washed thoroughly with distilled water before the test each time in order to avoid any interference effect. The elemental analysis was carried out using inductively coupled plasma-atomic emission spectrometry (ICP-AES).

Figures 10 and 11 give the cumulative leaching of $\mathrm{Ca}, \mathrm{Pb}$, $\mathrm{Cd}, \mathrm{Zn}, \mathrm{Mn}$, and $\mathrm{Cu}$ from NFA and $\mathrm{Ca}, \mathrm{Pb}, \mathrm{Cd}, \mathrm{Zn}, \mathrm{Mn}, \mathrm{Cu}$, and $\mathrm{Cr}$ from MFA as determined for different L/S ratios of 5 to 100 . It is a general observation that the leaching of any trace element increases with the increase in L/S ratio. The increase is steep up to a L/S ratio of 20 and then is gradual beyond 20 up to 100 . These results agree closely with those of Fytianos et al. [40] who concluded that the leaching of most of the trace metals generally from fly ashes and combustion residues increases with $\mathrm{L} / \mathrm{S}$ ratios. The leaching order of trace elements for a given fly ash is not affected with the increase in L/S ratio. The order of leachability for NFA (Figure 10) at any $\mathrm{L} / \mathrm{S}$ ratio varies in the order of $\mathrm{Ca}>\mathrm{Pb}>\mathrm{Cd}>\mathrm{Zn}>\mathrm{Mn}$ $>\mathrm{Cu}$. For MFA (Figure 11), the order is $\mathrm{Ca}>\mathrm{Cd}>\mathrm{Pb}>\mathrm{Mn}$ $>\mathrm{Cr}>\mathrm{Zn}>\mathrm{Cu}$. The variation in the order of leachabilities of trace elements for the fly ashes may be due to variations in $\mathrm{pH}$ at the given L/S ratio and the original concentrations of the elements present in the fly ashes. For both fly ashes, leachability of calcium is found to be far more than those of the other elements at any given liquid-to-solid ratio.

5.1. Effect of $p H$. In studying the effect of $\mathrm{L} / \mathrm{S}$ ratio on the leachability of trace elements, no attempt was made to maintain constant $\mathrm{pH}$ value. But it is known that the 


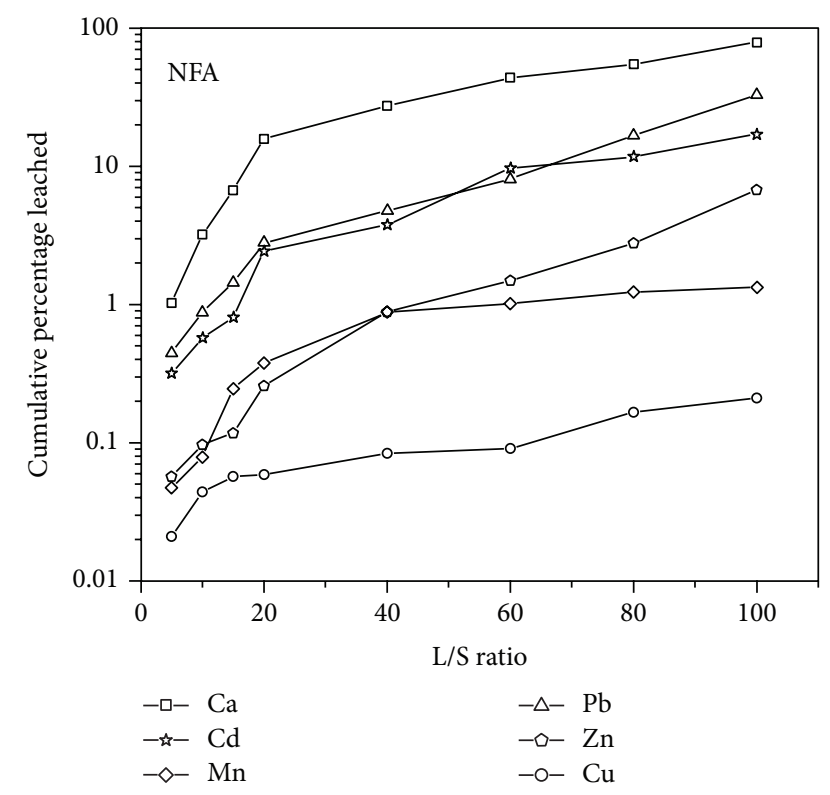

FIGURE 10: Cumulative percentage of various elements leached from NFA.

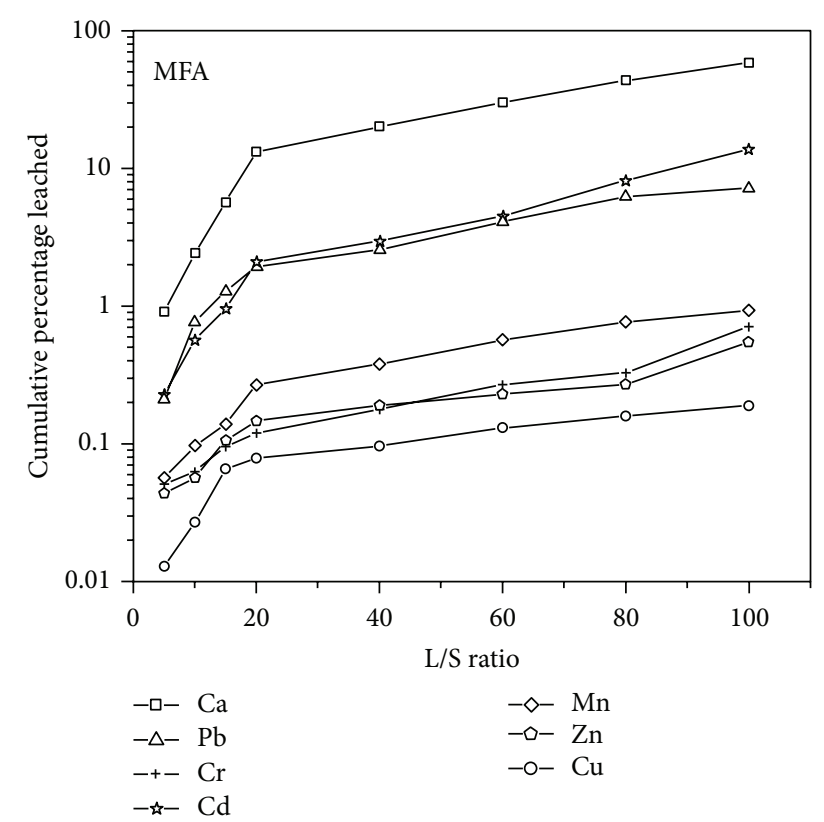

FIGURE 11: Cumulative percentage of various elements leached from MFA.

leachability of most of the trace elements is affected by $\mathrm{pH}$ of the leaching fluid. Leachability tests at constant $\mathrm{pH}$ values between 2 and 10 were performed, at a fixed L/S ratio of 20 . The $\mathrm{pH}$ of the slurry was maintained at a constant value by adding small amounts of $0.1 \mathrm{M} \mathrm{HCl}$ and $\mathrm{NaOH}$ solutions. The sensitivity of the $\mathrm{pH}$ adjustment was around \pm 0.2 in all the experiments. All the trace elements considered in the present study showed a characteristic maximum leachability at lower $\mathrm{pH}$ than at higher $\mathrm{pH}$ values (Figures 12 and 13). It can be attributed to the increase in the attack on the mineral phases

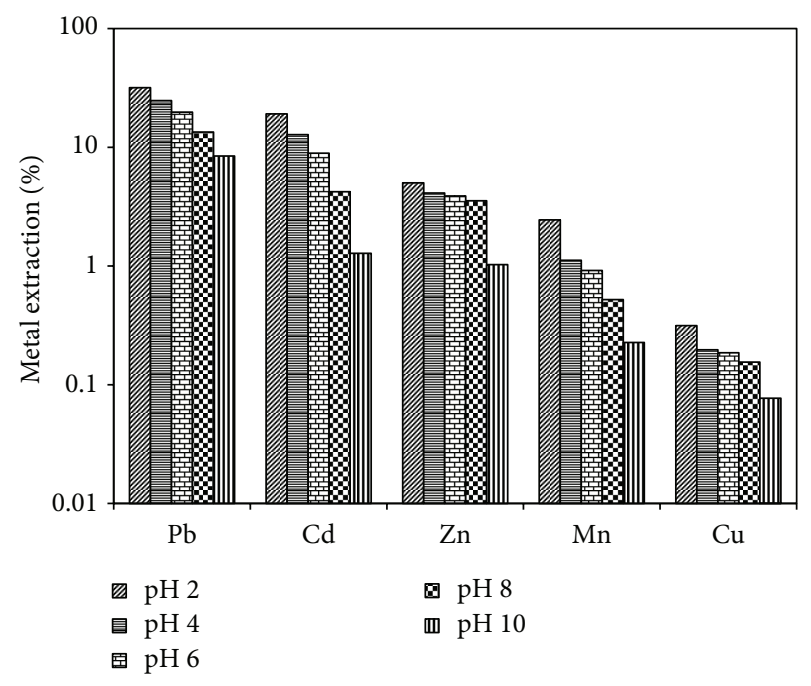

FIGURE 12: Leachability of metal ions at various $\mathrm{pH}$ conditions from NFA.

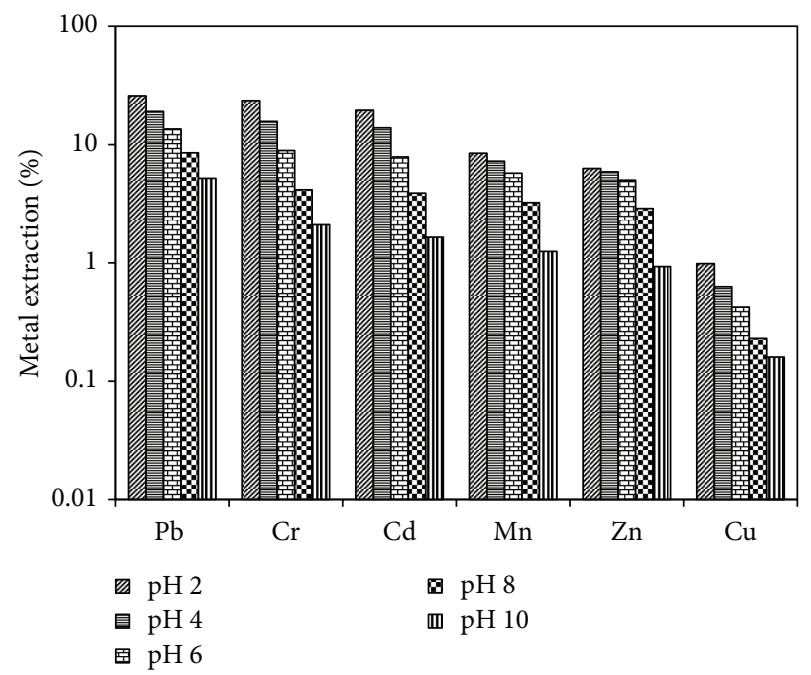

FIGURE 13: Leachability of metal ions at various $\mathrm{pH}$ conditions from MFA.

which contain these trace metals by hydrogen ions [41, 42]. Also at lower pHs, the metals usually exist in ionic state as they do not precipitate. For NFA (Figure 12), the leaching order of metals from $\mathrm{pH} 2$ to 10 is seen to be $\mathrm{Pb}>\mathrm{Cd}>$ $\mathrm{Zn}>\mathrm{Mn}>\mathrm{Cu}$, while that for MFA (Figure 13) it is $\mathrm{Pb}>\mathrm{Cr}>$ $\mathrm{Cd}>\mathrm{Mn}>\mathrm{Zn}>\mathrm{Cu}$. The order of leachability, by and large, is not affected by the $\mathrm{pH}$ of the leaching fluid. But the amounts of element leached are greatly influenced by the $\mathrm{pH}$ of the system. The amount of element leached depends to a certain extent on the amount of trace element present in the fly ash. This also, to a large extent, controls the order of leachability of elements from fly ashes. 


\section{Conclusions}

The physical properties, namely, particle size, surface area, zeta potential, and free swell index values, vary considerably for the fly ashes. MFA has greater finer particle content than NFA. Both fly ashes have predominantly quartz and mullite phases in them. The silica, total lime, and carbon contents, which have major influence on the pozzolanic reactivity of fly ashes, are different for both fly ashes. NFA has relatively higher free lime content compared to MFA. The surface morphological features reveal that MFA has rougher surface compared to that of NFA. Upon curing, both fly ashes develop sufficient unconfined compressive strength and stiffness as revealed from the CBR characteristics. Both fly ashes exhibit practically lower compressibility characteristics. It is observed that leachability of trace metals increases with the decrease in $\mathrm{pH}$ of the fly ash liquid system and increases with L/S ratio. Finer fly ashes show reduced leachability of metals due to their better adsorption capacities.

\section{Acknowledgments}

The author acknowledges both Engineering Research Centre at King Saud University, Riyadh, Saudi Arabia, and Engr. Abdullah Bugshan Research Chair for Expansive Soils, for providing the financial support and experimental facilities for the study. The author is grateful to Dr. Baig MYA, Retired Professor, SVUCE, Tirupati, India, for his kind assistance in preparing the paper. The author would like to thank the reviewers for their constructive comments which helped immensely in the cause of the paper.

\section{References}

[1] MOEF (Ministry of Environment and Forestry), In the Gazette of India Extraordinary, Part II-Section 3-Sub Section (ii), Ministry of Environment and Forests Notification, New Delhi, India, September 1999, http://envfor.nic.in:80/legis/hsm/ so763(e).pdf.

[2] ASTM C618, Standard Specification for Coal Fly Ash and Raw or Calcined Natural Pozzolan for Use in Concrete, ASTM, West Conshohocken, Pa, USA, 2008.

[3] ASTM D854, Standard Test Methods for Specific Gravity of Soil Solids by Water Pycnometer, ASTM, West Conshohocken, Pa, USA, 2006.

[4] A. A. B. Moghal, Enhancing the potential of class F fly ashes for geotechnical and geoenvironmental applications [Ph.D. thesis], Indian Institute of Science, Bangalore, India, 2010.

[5] M. R. Schure, P. A. Soltys, D. F. S. Natusch, and T. Mauney, "Surface area and porosity of coal fly ash," Environmental Science and Technology, vol. 19, no. 1, pp. 82-86, 1985.

[6] D. El-Mogazi, D. J. Lisk, and L. H. Weinstein, "A review of physical, chemical, and biological properties of fly ash and effects on agricultural ecosystems," The Science of the Total Environment, vol. 74, no. 1, pp. 1-37, 1988.

[7] S. V. Mattigod, D. Rai, L. E. Eary, and C. C. Ainsworth, "Geochemical factors controlling the mobilization of inorganic constituents from fossil fuel combustion residues: I. Review of the major elements," Journal of Environmental Quality, vol. 19, no. 2, pp. 188-201, 1990.
[8] T. L. Theis and K. H. Gardner, "Environmental assessment of ash disposal," Critical Reviews in Environmental Control, vol. 20, no. 1, pp. 21-42, 1990.

[9] J. E. Gillott, Clay in Engineering Geology, Elsevier Publishing Company, London, UK, 2nd edition, 1987.

[10] B. R. Puri and K. Murari, "Studies in specific area measurement of soil. I. Comparison of different method," Soil Science, vol. 96, no. 5, pp. 331-336, 1963.

[11] S. Lowell, ,Introduction to Powder Surface Area, John Wiley \& Sons, New York, NY, USA, 1979.

[12] J. P. Martin, R. A. Collins, J. S. Browning, and F. J. Biehl, "Properties and use of fly ashes for embankments," Journal of Energy Engineering, vol. 116, no. 2, pp. 71-86, 1990.

[13] N. S. Pandian, C. Rajasekhar, and A. Sridharan, "Studies of the specific gravity of some Indian coal ashes," Journal of Testing and Evaluation, vol. 26, no. 3, pp. 177-186, 1998.

[14] A. Sridharan, N. S. Pandian, and P. Srinivasa Rao, "Shear strength characteristics of some Indian fly ashes," Ground Improvement, vol. 2, no. 3, pp. 141-146, 1998.

[15] ASTM D422-63, Standard Test Method for Particle-Size Analysis of Soils, ASTM, West Conshohocken, Pa, USA, 2007.

[16] ASTM B822-02, Standard Test Method for Particle Size Distribution of Metal Powders and Related Compounds by Light Scattering, ASTM, West Conshohocken, Pa, USA, 2002.

[17] D. N. White and J. B. Dixon, "Scanning electron microscopy of minerals in soils," Texas Society of Electron Microscopy Journal, vol. 26, no. 1, pp. 9-11, 1995.

[18] BS: 1377, British Standard Methods of Test for soil for Engineering Purposes-Part 2: Determination of Liquid Limit, Preferred Method Using the Cone Penetrometer, British Standards Institution, London, UK, 1990.

[19] V. Yudhbir and Y. Honjo, "Application of geotechnical engineering to environmental control," in Proceedings of the 9th Asian Regional Conference on Soil Mechanics and Foundation Engineering, vol. 2, pp. 431-469, Bangkok, Thailand, 1991.

[20] M. G. Winter and B. G. Clarke, "Improved use of pulverised fuel ash as general fill," Proceedings of the Institution of Civil Engineers: Geotechnical Engineering, vol. 155, no. 2, pp. 133-141, 2002.

[21] K. L. Moulton, Technology and Utilization of Power Plant Ash in Structural Fills and Embankments, West Virginia University, 1978.

[22] A. Sridharan and P. V. Sivapullaiah, "Mini compaction test apparatus for fine grained soils," Geotechnical Testing Journal, vol. 28, no. 3, pp. 240-246, 2005.

[23] ASTM D2166, Standard Test Method for Unconfined Compressive Strength of Cohesive Soil, ASTM, West Conshohocken, Pa, USA, 2006.

[24] ASTM D5102, Standard Test Methods for Unconfined Compressive Strength of Compacted Soil-Lime Mixtures, ASTM, West Conshohocken, Pa, USA, 2009.

[25] A. M. Digioa and W. C. Nuzzo, "Fly ash as structural fill," Journal of the Power Division, vol. 98, no. 1, pp. 77-92, 1972.

[26] G. A. Leonards and B. Bailey, "Pulverised coal ash as structural fill," Journal of the Geotechnical Engineering, vol. 108, no. 4, pp. 517-531, 1982.

[27] B. Kim, M. Prezzi, and R. Salgado, "Geotechnical properties of fly and bottom ash mixtures for use in highway embankments," Journal of Geotechnical and Geoenvironmental Engineering, vol. 131, no. 7, pp. 914-924, 2005. 
[28] B. K. Hough, Basic Soils Engineering, John Wiley \& Sons Inc, NYSE, New York, NY, USA, 2nd edition, 1977.

[29] C. Rajasekhar, Retention and permeability characteristics of clays and clay-fly ash systems subjected to flow of contaminants [Ph.D. thesis], Indian Institute of Science, Bangalore, India, 1995.

[30] N. S. Pandian and S. Balasubramonian, "Permeability and consolidation behavior of fly ashes," Journal of Testing and Evaluation, vol. 27, no. 5, pp. 337-342, 1999.

[31] K. M. Skarzynska, A. K. M. Rainbow, and E. Zawisza, "Characteristic of ash in storage ponds," in Proceedings of the 12th International Conference on Soil Mechanics and Foundation Engineering, pp. 1915-1918, Rio de Janeiro, Brazil, August 1989.

[32] A. A. B. Moghal and P. V. Sivapullaiah, "Effect of pozzolanic reactivity on compressibility characteristics of stabilised low lime fly ashes," Geotechnical and Geological Engineering, vol. 29, no. 5, pp. 665-673, 2011.

[33] ASTM D2435, Standard Test Methods for One-Dimensional Consolidation of Soils Using Incremental Loading, ASTM International, West Conshohocken, Pa, USA, 2004.

[34] W. G. Holtz and H. J. Gibbs, "Engineering characteristics of expansive clays," ASCE Transactions, vol. 121, pp. 641-663, 1956, paper no. 2814.

[35] S. M. Rao and A. Sridharan, "Mechanism controlling the volume change behavior of kaolinite," Clays \& Clay Minerals, vol. 33, no. 4, pp. 323-328, 1985.

[36] A. Sridharan and K. Prakash, "Classification procedures for expansive soils," Proceedings of the Institution of Civil Engineers: Geotechnical Engineering, vol. 143, no. 4, pp. 235-240, 2000.

[37] D. F. S. Natusch, J. R. Wallace, and C. A. Evans Jr., "Toxic trace elements: preferential concentration in respirable particles," Science, vol. 183, no. 4121, pp. 202-204, 1974.

[38] H. van der Sloot, O. Piepers, and A. Kok, "A standard leaching test for combustion residues," Tech. Rep. OSTI ID: 7005861, Energieonderzoek Centrum Nederland, SOSUV, Amsterdam, The Netherlands, 1984.

[39] USEPA, Tests Methods for Evaluating Solid Waste, Physical Chemical Methods, SW-846, Method 3050B, US Environmental Protection Agency, Washington, DC, USA, 1996.

[40] K. Fytianos, B. Tsaniklidi, and E. Voudrias, "Leachability of heavy metals in Greek fly ash from coal combustion," Environment International, vol. 24, no. 4, pp. 477-486, 1998.

[41] T. Praharaj, M. A. Powell, B. R. Hart, and S. Tripathy, "Leachability of elements from sub-bituminous coal fly ash from India," Environment International, vol. 27, no. 8, pp. 609-615, 2002.

[42] P. V. Sivapullaiah and A. A. B. Moghal, "Leachability of trace elements from two stabilized low lime indian fly ashes," Environmental Earth Sciences, vol. 61, no. 8, pp. 1735-1744, 2010. 

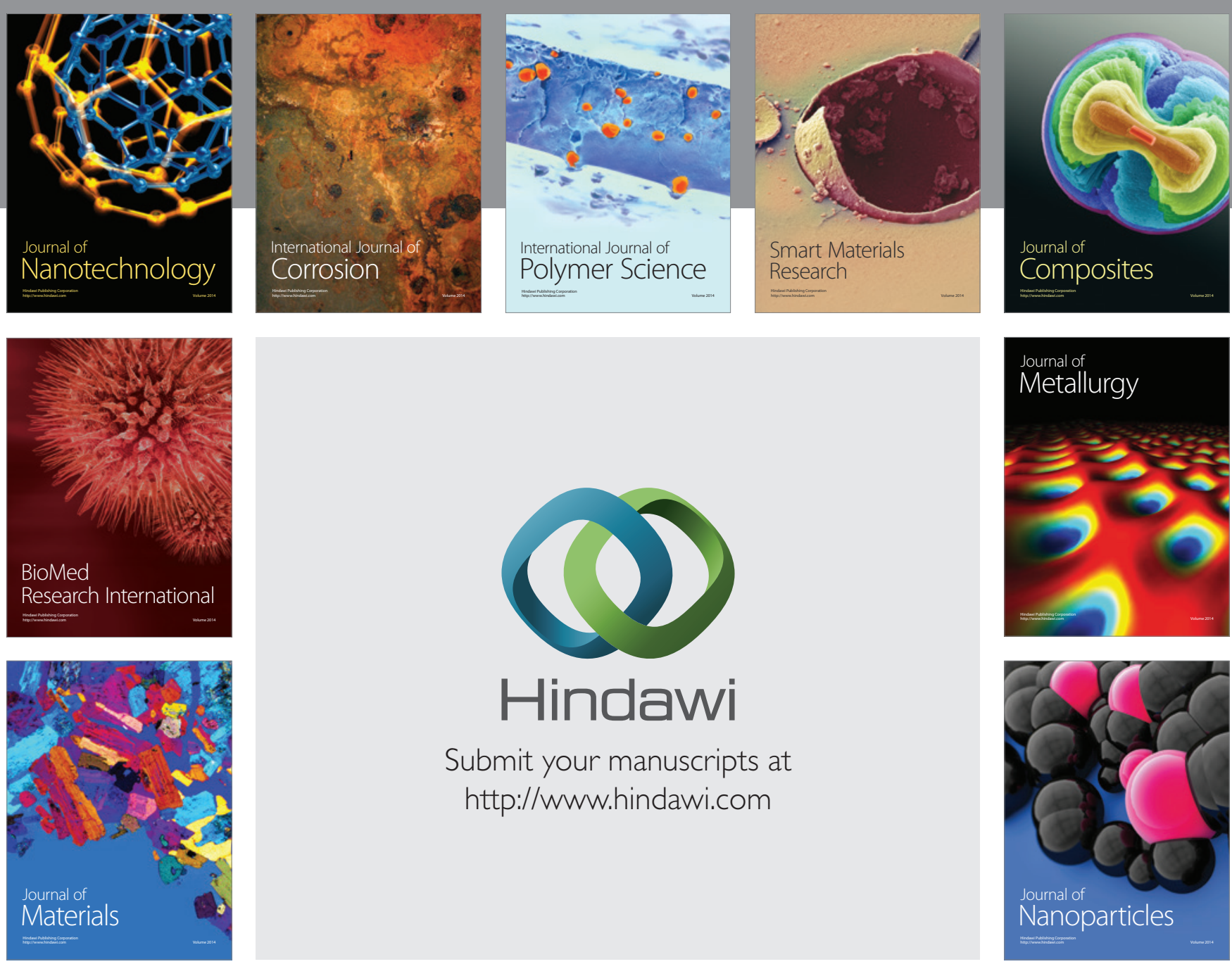

Submit your manuscripts at http://www.hindawi.com
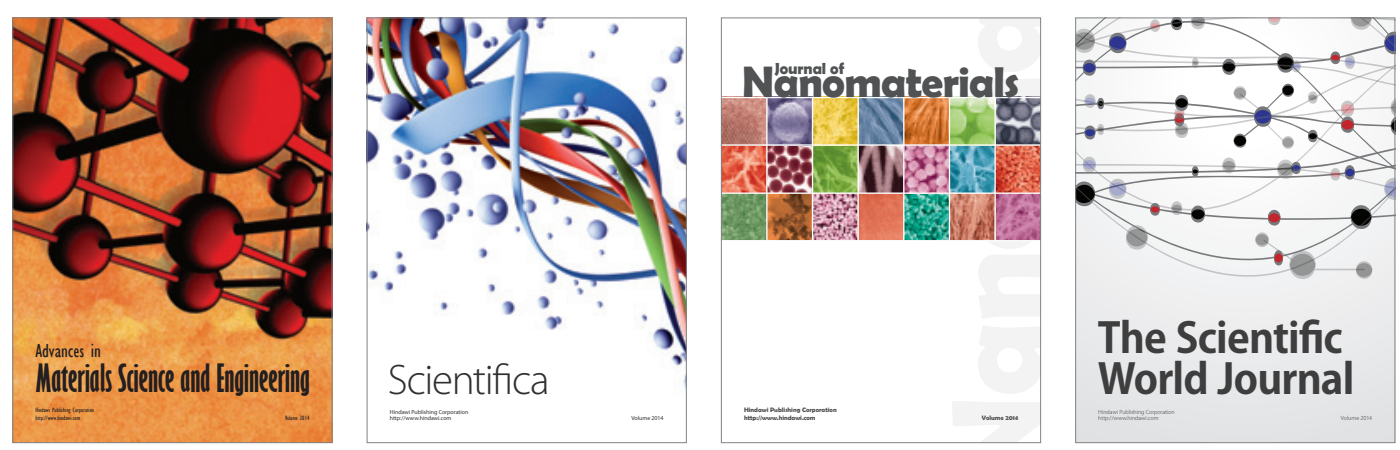

\section{The Scientific World Journal}
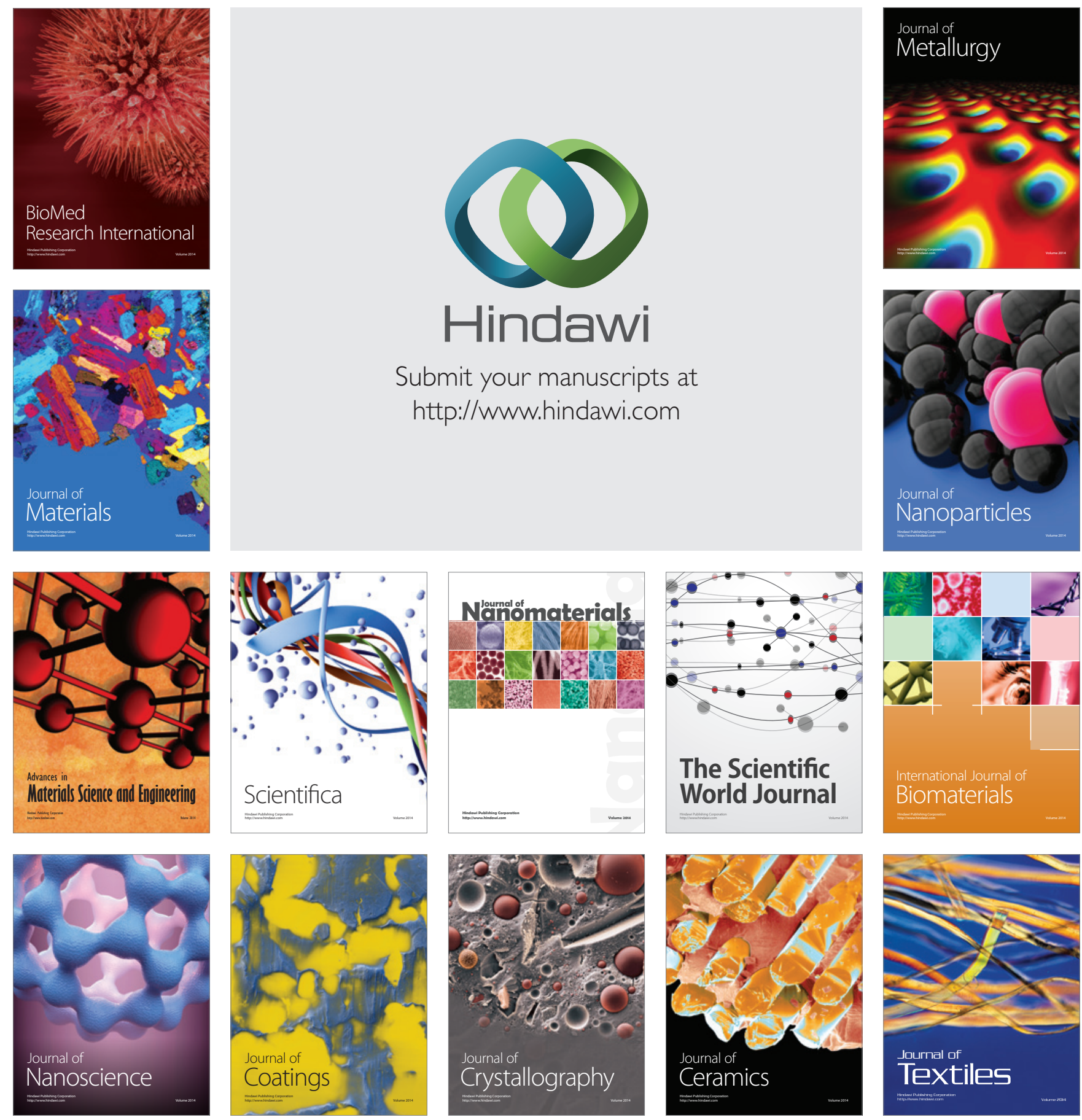